\title{
ON A POSSIBLE CHARACTERISTIC OF THE GOVERNING SYSTEM OF PHARAOH AMENHOTEP IV (AKHENATEN)
}

\author{
Tarmo Kulmar \\ Chair of Comparative Religious Studies \\ University of Tartu, Estonia \\ e-mail:tarmo.kulmar@ut.ee
}

\begin{abstract}
The article explores the relationship between the religious reform of Pharaoh Amenhotep IV (Akhenaten) of the New Kingdom of Ancient Egypt and the changes in the governing system. The analysis, which is based on historical data and structured after the concept of the early totalitarian state set forth by the author, reveals that Akhenaten's governing system corresponds (almost) fully to that of an early totalitarian state in terms of historical and political causes and ideological factors, and partly in terms of administrative and legislative systems, whereas only an occasional feature of early totalitarianism is observable in economy and social order. No features of early totalitarianism in Akhenaten's governing system are manifested in foreign policy. It can be concluded, quite confidently, that Pharaoh Amenhotep IV (Akhenaten) was heading towards an early totalitarian form of government and that Akhenaten's experiment may have been one of the first known endeavours in the history of mankind to establish an early totalitarian state.
\end{abstract}

Keywords: Amenhotep IV (Akhenaten), Ancient Egypt, early totalitarianism, government, ideology, monotheism, religion

\section{INTRODUCTION}

The following is a research of the revolutionary steps in the realm of religion undertaken by Amenhotep IV (1350-1334 BC)1, one of the foremost monarchs of the so-called imperial, or New Kingdom, period (1570-1070 BC) $)^{2}$ of Ancient Egypt, with the focus on how the religious reform was reflected in his governmental actions. First, a brief overview is given of the socio-political structure that had evolved in Egypt by the time of the eighteenth dynasty (1570-1293 BC) of the New Kingdom, which is followed by a scrutiny of Amenhotep IV's major measures in domestic policy. Finally, his activities are assessed against 
the concept of the so-called early totalitarian state. The author's objective is to investigate whether and to what extent it is possible to refer to the governing system of Amenhotep IV (Akhenaten) as an early totalitarian state.

The primary written sources for the period under study are the Amarna epitaphs and epigraphs (incl. hymns to Aten) and the Amarna Letters (see, e.g., Murnane 1995; Moran 1992). May it be emphasised hereby that the author is not an Egyptologist and therefore relies on the works of renowned scholars, using the material on Ancient Egypt only to illustrate his aforementioned concept. The author considers it necessary to explicitly emphasize the methodological fact that this paper focuses primarily on the development of early totalitarian conception, at which the data is only evidence of Egyptology. In this regard, however, the professional Egyptologists should be trusted.

\section{THE NEW KINGDOM, AMENHOTEP IV (AKHENATEN) AND HIS REFORMS}

By the time Pharaoh Amenhotep IV acceded to the throne, Egypt had become the most powerful nation of the ancient world, especially thanks to the military might resulting from the successful campaigns, expedient political deals and skilful administration of his able predecessors Thutmose III and Amenhotep III, domestic stability, and economic prosperity. According to a widely accepted view (e.g. Grimal 1992; see also Doherty 2004: 33-44), the unifying factors for the state were as follows:

- The pharaoh as a ruler of essentially unlimited power, who was simultaneously the political, military and religious ruler, the intermediary between people and gods, was worshipped as a living god on earth.

- In addition to the patron gods of the nomes, a pantheon of deities highly venerated all over Egypt had evolved. Preeminent were Amun-Ra (Amun, once the patron god of Thebes, had become the chief god and merged with the sun god Ra), the fertility gods Osiris and Isis, and the personification of the world order Maat.

- The army, which included the infantry, the cavalry, the chariotry, and the navy, was comprised of professional and, in wartime, forcibly conscripted soldiers, as well as of foreign mercenaries. Law and order were enforced by garrisons stationed in key centres.

- An influential priesthood, especially the high priests, to whom the principal religious duties of the pharaoh were delegated. The highest-ranking of them was the chief priest of the Amun-Ra temple in Thebes, whose authority 
tended to jeopardise pharaonic power, especially in the final stages of the New Kingdom. The temples were important centres of economy, education, and culture.

- The officialdom, which partly coincided with the lower priesthood, was composed of the scribes, the accountants, and the supervisors. Owing to clan relationships, access to classified information and high positions in the court, a great many of them were corrupt (to use the modern terms).

- Central rites, such as the rite of Osiris, dedicated to the rebirth and periodic revival of nature, as well as the cult of the dead and the other world, which signified preparation for death from fairly early on in one's lifetime, including, if possible, the construction of a tomb and the accumulation of means for mummification and for copious grave goods in order to ensure eternal life.

We see that apart from political, economic, and social factors, religious and - in modern terms - ideological ones were at least as important.

The pharaoh's birthname was Amen-Hotep (Amun is Satisfied). In the fifth year of his rule, he adopted a new birthname - Akhen-Aten (Pleasing to Aten). Yet, all through his reign he had one and the same royal, or throne, name: Nefer-Heperura-Ra (Beautiful Are the Regeneses of Ra) (Clayton 2001: 120). He was the second son of Amenhotep III and his main wife (Great Royal Wife) Tiye. He was probably asked to accede to the throne after the death of his elder brother, to become coregent with his father in the final years of the latter's life, as was customary in Egypt. He staged his coronation in the temple of the sun god Ra-Harakhte at Hermonthis in South Egypt (Jacq 2000: 46), married Nefertiti - daughter of Minister Aye, his mother's (Queen Tiye's) brother (i.e. his uncle's daughter) (Jacq 2000: 120-121; see also David 2005: 206) - who, based on the busts found from the ruins of Tell el-Amarna, may be considered one of the most beautiful women in history; may it be mentioned that the name "Nefertiti" meant "The Beautiful One Has Returned" (Stadnikov 1998: 320). Thus, the first four or five of the seventeen years of Amenhotep IV's reign were completely conventional. The revolutionary measures were delayed until the next decade.

Although initially the pharaoh had himself be depicted, as the custom went, with the chief god Amun, he started to increasingly prefer the sun disc Aten. This aspect of the sun god Ra had already been venerated by his predecessors Thutmose IV and Amenhotep III. Amenhotep IV built an Atenist temple at Karnak in Thebes and gave a new meaning to the cult of Aten. After changing his birthname to Akhenaten, he initiated a systematic reformation, increasingly resorting to repressive means, among others. 
As a first measure, Amenhotep IV removed from Thebes the high priest of the temple of Amun, sending him to an eastern desert to lead an expedition, for the priesthood of the old chief god Amun was undoubtedly the main enemy of the new religious movement. At Karnak, he built the aforementioned temple to Aten, a vivid expression of the new artistic style, after which the pharaoh was portrayed in a naturalistic manner, with his physical properties, a phenomenon unprecedented until then. Artistically, he now had Aten depicted as the sun disc, the only anthropomorphic feature thereof being human hands at the ends of the rays. Theologically, it denoted the idea of a universal world religion, according to which Aten was the god besides whom there was no other (Stadnikov 1998: 317). Ethnically, it was echoed in an equally unparalleled idea that in Aten's eyes all peoples and languages (see Assmann 1975: 218-219), Egyptians and foreigners alike, had the same worth (see Hornung 1978 [1965]: 99), since they were all Aten's children. It is fairly certain, however, that Akhenaten did not preach the equality of all people, this being implied in the fact that in the first period of the reformation there was no persecution of either the old gods or their worshippers, who constituted an overwhelming majority of the Egyptian population. In addition, Akhenaten ousted a large part of the old officialdom, inviting into his court officials, military officers, and priests who did not descend from the upper class or were even foreigners. The pharaoh was raising allies for himself.

Having prepared a base of loyal supporters, Akhenaten progressed to the central phase of his endeavours. Here, likewise, several stages can be distinguished.

Firstly, he abandoned both the new capital, Thebes, and the old one, Memphis, and founded between them, approximately halfway from either end, a new royal capital Akhet-Aten (The Horizon of Aten). It was a solitary site with no ties to cults of other gods. Nowadays, this site is identified as Tell el-Amarna. Probably, Akhenaten himself had been among the authors of the very exceptional layout of the city. The economic policy of the state had to be restructured, as hosts of unskilled and skilled labour were to be forcibly redirected there, as was a substantial share of the revenue in order to procure building materials, provisions, and other requisites (Jacq 2000: 62-65). Owing to the fast pace, the massive construction works bore marks of great haste (Jacq 2000: 74). The new court, headed by Akhenaten, moved into the uncompleted city already the next year. After Akhenaten's death, Akhetaten was deserted (about Akhetaten, see, with references, Wilkinson 2013: 244-246 and 465-468; also Darnell \& Manassa 2007: 189-196; David 2005: 209-214). This, too, was unprecedented in Egyptian history, which epitomised the tradition of permanence and continuity. 
Secondly, as the opposition of the priests of Amun evidently grew and the anti-Atenist agitation all across the nation undoubtedly intensified, Akhenaten set out, as a countermeasure, to destroy the cult of Amun in the fifth year of his reign at the latest. Attempts were made to erase the name of Amun from inscriptions everywhere in order to doom it to oblivion. The enmity was also extended to the other gods. Akhenaten proclaimed that Aten no longer tolerated the existence of any other deity, disbanding their priest and redirecting the revenue from their temples to Aten's benefit (David 2005: 209). Compliance with the command was monitored by the pharaoh's security service, and those remaining loyal to the old religion were repressed (Wilkinson 2013: 253-254; Jacq 2000: 150ff.).

A god being proclaimed false and his cult being decreed to destruction was an unheard-of action in the then history of not only Egypt but probably of the whole of humanity.

At the same time, Akhenaten promoted the cult of Aten as a monotheistic one, which was alien to the Egyptians theologically as well as ritualistically. The rich mythology of the earlier religion was brushed aside altogether, supplanted by hymns to Aten, part of which were probably composed by Akhenaten himself (see, e.g., Wilkinson 2013: 251-252; Lichtheim 1976: 96-99; David 2005: 215-217). The temples to Aten contained no sanctuaries or cultic images. The primary feature of the rite was that the chief priest of Aten was Akhenaten himself, the king being the only earthly representative of the god. Unlike the previous rites, which were conducted in temples, the king was worshipped as a god in his palace (see Shafer 1997: 180-183). Special emphasis was on public processions, which had a profound effect (Jacq 2000: 146ff., 178). The cult of the monarch and his family as the so-called domestic deities even developed, which again was an entirely novel phenomenon in Egyptian religion (see Morenz 1984: 155; Assmann 1984: 251-253). In essence, Aten and Akhenaten had become one. Hence, it represented an extraordinary - even a totalistic - attempt to absolutise the king's person (see Dodson 2009; Stadnikov 1998: 43), which included both the secular and the religious realm.

Such radical measures incurred a series of setbacks. By relocating to a new capital, Akhenaten largely removed himself from reality, as the relatives of the previous pharaoh, the authoritative figures in the old court and the competent officials, whose power Akhenaten failed to conclusively break, effectively continued to govern Egypt from both of the old capitals. After all, the state had to function.

The cults of the chief god Amun and of the other gods did not cease either. The priests of Amun, who wanted to maintain their leading position in the 
religious life of the nation, incited anti-Atenist sentiments. The majority of the common people continued to worship the old gods, since the mysticist Atenist theology was simply incomprehensible to the peasants and urban paupers.

It may be assumed that in reality the Atenist ideal state existed only on the narrow strip of Akhetaten. Disagreeable facts were withheld from the pharaoh; he was ill-informed of the actual situation in the state (see, e.g., Jacq 2000: 178). Taxes came in irregularly, an escalating economic decline (Jacq 2000: 182) prompted sporadic boycotts and local rebellions, which the pharaoh strove to suppress mainly with the help of foreign mercenaries (Stadnikov 1998: 319).

The foreign policy of the Egyptian Empire was disastrous. As appears from the copious cuneiform correspondence with governors and other rulers of the subjugated regions found from the ruins of Amarna (see Moran 1992), Egypt lost its influence over almost all the territories in Syria and Palestine, which had previously been under its vassalage. The reason was both the pharaoh being busy with domestic policy problems and the Hittite-led revolts. It was not until the time of the nineteenth dynasty that Egypt managed to restore a measure of its once glorious foreign policy.

The fiascos in domestic and foreign policy were coupled with flaws in the pharaoh's private life. Nefertiti bore Akhenaten six daughters, who evidently were handicapped either physically or mentally and did not all reach adulthood. In the last years of the pharaoh's reign, Queen Nefertiti disappears from the annals; apparently she fell into disfavour and died young. In the last three years of his life, Akhenaten co-reigned with his son-in-law Semenhkara, who managed to strike a compromise with the priests of Amun. This so-called restoration period may be regarded as one of dual religious power. Under Ay, Tutankhamun, and Horemheb, the rulers after Akhenaten's death, the cult of Aten gradually faded into oblivion and the old religion was restored relatively peacefully. Systematic annihilation of the memory and memorials relating to Akhenaten did not begin until the nineteenth dynasty pharaohs Seti I and Ramesses II (Jacq 2000: 210).

Akhenaten's so-called revolution failed, for he tried to forcibly impose religious ideas that remained incomprehensible to the people for the lack of, among others, a nationwide cult and a motivating mythology, as well as for the fact that the new religion pursued to perpetuate a non-Osiric concept of the afterlife and terminate the habitual burial customs (David 2005: 229-230). The religion of Aten did not muster the support of the upper classes due to political and economic reasons.

In fact, religious ideologies reflecting universalistic tendencies as well as pursuits of implementing such ideas have surfaced all through the long history 
of the ancient Egyptian state (see Stadnikov 1998: 93-142, with extensive literature on the topic). In this regard, Akhenaten is no exception. Despite radical and resolute measures, however, his effort failed, for the idea of monotheism was alien to the Egyptians. It has been suggested (Hornung 1983: 191ff.; 1992: 43-49) that the traditionally polytheistic Egyptians could not conceive of the oneness of god and therefore of monotheism, and that the introduction of monotheism automatically involved a fundamental shift in logic. With his action, Akhenaten changed the traditional beliefs too radically (see Aten's Hymn, Lichtheim 1976: 96-100). Perhaps the venture would have met with more success had the religious reform been effected in stages and Aten initially promoted as one of the henotheistic main gods among others.

One of Akhenaten's motives was undoubtedly his religious perceptions, and to an extent he was an idealist, which is manifested, among others, in his exodus to Akhetaten - his 'kingdom of Aten'. Furthermore, neither the Atenist theology nor Akhenaten's religious worldview (which, in essence, were one and the same!) had any room for the dark sides of real life (Stadnikov 1998a: 319). On the other hand, one must not underestimate his ambition for political monocracy, to that end eliminating powerful political groupings (the priests of Amun, the old aristocracy, and the corrupt high officialdom); as well, he had enough resolve to employ repressive measures, which enabled him to reign as long as he did (Darnell \& Manassa 2007: 189-196). Accordingly, it appears that the scholars who have tried to demonstrate that Akhenaten used the cult of Aten to suppress the priests of Amun-Ra and to restore the supremacy of the royal power may be substantially right (e.g. Redford 1984).

\section{ANALYSIS}

Let us now examine the political situation during Amenhotep IV's reign in the context of the concept of the so-called early totalitarian state, set forth previously by the author. The author first used the concept in connection with the Tahuantinsuyu regime of the ancient Peruvian Incas (Kulmar 2002; see also Kulmar 2003) ${ }^{3}$, later also in determining the system of government of the Qin State in Ancient China (Kulmar 2007; 2011; 2014).

According to the said concept, the following key factors may be discerned about the early totalitarian state (Kulmar 2002: 40-42):

- historical and political reasons for the rise and demise of the system;

- governance and administration;

- economy; 
- social life;

- legal order;

- ideology;

- foreign policy.

These factors have a number of features that I will address in the following analysis. If a regime or a government system matches all the features given below, it represents an ideal case of the early totalitarian state, as the empires of Tahuantinsuyu and Qin very probably did. The less a government system displays the following features, the smaller is the potential degree of totalitarianism in it. Naturally, the more information is available about a particular case, the greater is the likelihood of a correct assessment.

How does Akhenaten's system of government tally with the features of the early totalitarian state based on the available (unfortunately fairly scanty) information about the aforementioned key factors?

\section{Historical and political reasons for the rise and demise of the system}

The existence of a domestic or foreign policy crisis situation; creation of the system in a subjective manner (centred around the person of the sovereign), taking advantage of objective risk factors; a relatively short duration; the demise of the system due either to an inner crisis or foreign pressure.

Amenhotep III bequeathed his son a flourishing state. It is not impossible, however, that Akhenaten sensed various pressures that he considered a threat to the royal power: political pressure by the priesthood and economic pressure (evidently) by the corrupt officialdom. The initiator and implementer of the reforms was Pharaoh Akhenaten himself as he began to restrain the power of the priests and the old court. The reforms lasted a mere decade. The system collapsed due to the emergence of extensive opposition and the failure of a "topdown" revolution. In summary, the case of Akhenaten corresponds to all the features of the factor.

\section{Governance and administration}

The elite's isolation from the people; strictly centralised government; extreme bureaucratisation of the officialdom; maximal control over the spread and consumption of information. 
It may be assumed that the pharaoh's exodus to Akhetaten resulted in his not being fully aware of the actual circumstances, particularly of the failures in the realisation of his reforms. At the same time, the pharaoh had contacts with the common people at the public ceremonies of the cult of Aten. The central government could not function effectively due essentially to dual power between the old and the new court governing from different capitals. There is no reason to regard Akhenaten's officialdom as more bureaucratized than that of Amenhotep III - rather, Akhenaten attempted to curb the old officialdom's power. Assumedly, there were several opposing tendencies in information control: the pharaoh sought to show the people that the cult of Aten was popular and successful; the priests and the conventionalists strove to conceal from the court at Akhetaten noncompliance with the pharaoh's commands; and the court at Akhetaten attempted to hide the actual situation from the pharaoh. As the economic conditions worsened, some regulation of food consumption might have been the case, although there is no evidence to prove that. In summary, the case of Akhenaten matches the features of the factor partly and conditionally.

\section{Economy}

Dominance of public ownership over private ownership or no private ownership; orientation towards a maximally autarkic economy; centralised and rigid planning and control of production and consumption; universal labour conscription; artificially imposed market relations; governmental coercion in the realisation of major projects.

There were several kinds of ownership in Egypt, but private ownership in various forms predominated. Many of the early economies, the Egyptian one included, were rather autarkic by nature, with the role of foreign trade being relatively small and primarily relating to non-necessities. Akhenaten is not known to have attempted to establish anything similar to planned economy. There was no universal obligatory labour conscription, although it might have occurred occasionally in the construction of the capital. As the economic decline escalated, there might have been efforts towards the end of the period at food rationing, but this is mere speculation. Although all through the history of Egypt large masses of people have been forcibly exploited to build labour-intensive facilities, in Akhenaten's case the tendency is manifested in the speedy erection of Aten's temples and, in particular, of the new capital Akhetaten. Consequently, the features of the factor tally with Akhenaten's case only to a small degree. 


\section{Social life}

Orientation towards regulation of the way of life using governmental planning and control mechanisms; restriction of freedom of movement and other personal liberties; segregation against certain social classes; assimilation of certain social groups; systematic suppression of minorities up to total annihilation; governmental demographic control.

Akhenaten is not known to have attempted to interfere in the traditional way of life of the working people or restrict the freedom of movement or other statusrelated freedoms. If any, those who were discriminated were unquestionably public supporters of the cult of Amun-Ra and saboteurs of the reforms, who were probably not a small segment. There is no information about terrorisation of minorities - quite the reverse, Akhenaten proclaimed ethnic and linguistic parity in line with Atenist theology. As far as is known, no population control mechanisms were established in Egypt. In summary, the features of the factor match Akhenaten's case only marginally.

\section{Legal order}

Legislation proceeding from the principle "that which is not permitted is prohibited"; cruel punishments; the dominance of collective responsibility over individual responsibility; persecution of dissenters; existence of a repressive apparatus.

Neither the legal order nor the laws of Egypt are known to have experienced significant changes towards greater stringency under Akhenaten. There is no information concerning collective responsibility being applied in greater measure than before to whole communities for an individual's infringement. However, the pharaoh specifically mandated monitoring of the implementation of his orders regarding the replacement of the officialdom, the restriction of the power of the priests of Amun and the introduction of the cult of Aten, and the abandonment of those of the old gods. There was a respective apparatus to monitor that and to punish the transgressors. Consequently, the case of Akhenaten agrees with the features of the factor partially. 


\section{Ideology}

The philosophy or religion underlying the system has been turned into the official state religion by the special propaganda apparatus; mythologised personality cult; orchestrated mass ceremonies; indoctrinated ethnocentrism; biased educational and cultural policy; censorship of public information and interpretation of history to achieve unified thinking.

Akhenaten's reforms were based on his self-made monotheistic cult of Aten, which acquired the status of state ideology. It was propagated and inculcated by the Atenist priesthood established to that very end. At state level, the cult of Aten was identified with the personality cult of Pharaoh Akhenaten. In honour of Aten and the pharaoh, public rites attended by large crowds were conducted. We cannot speak of any ethnocentrism in that particular period. Dogmatic xenophobia being largely alien to the Egyptians, the New Kingdom period in particular opened up ample opportunities for foreigners (Stadnikov 1998: 23), and Akhenaten even preached the parity of all people before Aten. The pharaoh enjoined systematic propagation of the Atenist doctrine. Censorship of information and history is indicated by actions undertaken to doom the cult of Amun and, in some measure, those of the other gods, to oblivion. Consequently, the case of Akhenaten, with a single exception, tallies fairly fully with the features of this factor.

\section{Foreign policy}

Drive for political hegemony over neighbouring territories; perpetual preparation for aggression and constant willingness to commit aggression; systematic implementation of the state's foreign policy from the position of power and by military means.

With a few exceptions, these features are actually typical of the foreign policy of Ancient Egypt's New Kingdom as a whole, Akhenaten's reign, however, being one of the exceptions. It may even be argued that foreign policy was the least successful area of Akhenaten's government on account of the pharaoh's being poorly informed and constantly immersed in internal affairs. Thus, Akhenaten's case does not agree with the features of the factor. 


\section{CONCLUSIONS}

It appears from the above that Akhenaten's system of government corresponds to the features of the early totalitarian state fully or almost fully only under the factors of historical and political reasons and ideology, whereas in terms of administration and legal order the correspondence is but partial. To a small degree, Akhenaten's reign reveals early totalitarian features in the areas of economy and social life. Only the foreign policy factor shows Akhenaten's system of government void of any early totalitarian features.

In summary, it may be assumed with a high degree of probability that Pharaoh Amenhotep IV alias Akhenaten was heading towards an early totalitarian system of government. The historical and political conditions were favourable, he had a suitable ideology that he vigorously propagated, and he had reached fairly far in creating a corresponding administrative and legal order. However, the economic and social systems are such areas of public life that require more time for cardinal restructuring. It was precisely what Akhenaten did not have his large-scale reform efforts lasted just over a decade.

Accordingly, Akhenaten's experiment may have been one of the earliest known attempts in human history at establishing an early totalitarian state.

\section{ACKNOWLEDGEMENTS}

The article is connected with Estonian Research Foundation Grant no. 6626 and the Estonian Research Funding Project of the Estonian Research Agency no. 500 (PUT500).

\section{NOTES}

1 Also 1364-1347 BC (see Stadnikov 1998: 313) or 1379-1362 BC (see David 2005: 359).

2 Dating based on Clayton 2001: 120.

3 The author first presented the concept in a systematised form in German in 2002. 


\section{REFERENCES}

Assmann, Jan 1975. Ägyptische Hymnen und Gebete. Zürich \& München: Artemis.

Assmann, Jan 1984. Ägypten: Theologie und Frommigkeit einer frühen Hochkultur. Stuttgart: Kohlhammer.

Clayton, Peter A. 2001. Vaaraode kroonika: Vana-Egiptuse valitsejad ja dünastiad valitsemisaegade kaupa. [A Chronicle of Pharaohs: Ancient Egyptian Rulers and Dynasties by Reigns.] Transl. by Kätlin Kaldmaa. Tallinn: Eesti Entsüklopeediakirjastus.

Darnell, John Coleman \& Manassa, Colleen 2007. Tutankhamun's Armies: Battle and Conquest During Ancient Egypt's Late 18th Dynasty. Hoboken, NJ: John Wiley \& Sons.

David, Rosalie 2005. Religioon ja maagia Vana-Egiptuses. [Religion and Magic in Ancient Egypt.] Transl. by Olavi Teppan. Tallinn: Tänapäev.

Dodson, Aidan 2009. Amarna Sunset: Nefertiti, Tutankhamun, Ay, Horemheb, and the Egyptian Counter-Reformation. Cairo \& New York: The American University in Cairo Press.

Doherty, Paul 2004. Tutanhamon: Vaarao mõistatuslik surm. [The Mysterious Death of Tutankhamun.] Transl. by Matti Piirimaa. Tallinn: Kunst.

Grimal, Nicolas A. 1992. A History of Ancient Egypt. Transl. by Ian Shaw. Oxford, UK \& Cambridge, MA: Blackwell.

Hornung, Erik 1978 [1965]. Grundzüge der ägyptischen Geschichte. Darmstadt: Wissenschaftliche Buchgesellschaft.

Hornung, Erik 1983. Conceptions of God in Ancient Egypt: The One and the Many. Transl. by John Baines. London \& Melbourne \& Henley: Routledge.

Hornung, Erik 1992. The Rediscovery of Akhenaten and His Place in Religion. Journal of the American Research Center in Egypt, Vol. 29, pp. 43-49. http://dx.doi. org/10.2307/40000483.

Jacq, Christian 2000. Nofretete ja Ehnaton. [Nefertiti and Akhenaten.] Transl. by Evelin Rand. Tallinn: Kunst.

Kulmar, Tarmo 2002. Die Totalität des Inkareiches und die Rolle der Religion. Trames, Vol. 1, No. 6 (56/51), pp. 38-49.

Kulmar, Tarmo 2003. Totalitarianism and the Role of Religion in the Inca State. Folklore: Electronic Journal of Folklore, Vol. 23, pp. 25-39. http://dx.doi.org/10.7592/ FEJF2003.23.incastate.

Kulmar, Tarmo 2007. Vana-Hiina Qini keisririigi valitsemissüsteemi olemusest. [On the System of Government in Qin Empire in Ancient China.] Mäetagused: Hyperjournal, Vol. 35, pp. 141-153. http://dx.doi.org/10.7592/MT2007.35.kulmar.

Kulmar, Tarmo 2011. Hiina keisririigi valitsemisviisi võimalikust eripärast Sui dünastia ajal (581-618). [On a Possible Characteristic of the Governing System of Chinese Empire during the Time of the Sui Dynasty (581-618 AD).] Mäetagused: Hyperjournal, Vol. 47, pp. 125-134. http://dx.doi.org/10.7592/MT2011.47.kulmar.

Kulmar, Tarmo 2014. On the Nature of the Governing System of the Qin Empire in Ancient China. Folklore: Electronic Journal of Folklore, Vol. 59, pp. 165-178. http://dx.doi.org/10.7592/FEJF2014.59.kulmar. 
Lichtheim, Miriam 1976. Ancient Egyptian Literature. Vol. 2. The New Kingdom. Berkeley \& Los Angeles: University of California Press.

Moran, William L. (ed.) 1992. The Amarna Letters. Baltimore \& London: The Johns Hopkins University Press.

Morenz, Siegfried 1984. Gott und Mensch im alten Ägypten. Leipzig: Koehler \& Amelang.

Murnane, William J. 1995. Texts from the Amarna Period in Egypt. Atlanta, Georgia: Scholars Press.

Redford, Donald B. 1984. Akhenaten: The Heretic King. Princeton: Princeton University Press.

Shafer, Byron E. (ed.) 1997. Temples of Ancient Egypt. Ithaca: Cornell University Press.

Stadnikov, Sergei 1998. Vana-Egiptuse kultuurilugu: Valitud artikleid, tôlkeid ja esseid. [The Cultural History of Ancient Egypt: Selected Articles, Translations and Essays.] Tallinn: Kodutrükk.

Wilkinson, Toby 2013. Vana-Egiptuse tõus ja langus. [The Rise and Fall of Ancient Egypt.] Transl. by Jana Linnart. Tallinn: Tänapäev. 